Article

\title{
Honeydew Deposition by the Giant Willow Aphid (Tuberolachnus salignus) Affects Soil Biota and Soil Biochemical Properties
}

\author{
Kyaw Min Tun ${ }^{1}$, Andrea Clavijo McCormick ${ }^{1} \mathbb{D}$, Trevor Jones ${ }^{2}$, Stanislav Garbuz ${ }^{1}$ and \\ Maria Minor ${ }^{1, *}$ \\ 1 Wildlife and Ecology Group, School of Agriculture and Environment, Massey University, \\ Private Bag 11222, Palmerston North 4410, New Zealand; k.m.tun@massey.ac.nz (K.M.T.); \\ A.C.McCormick@massey.ac.nz (A.C.M.); s.garbuz@massey.ac.nz (S.G.) \\ 2 Plant \& Food Research, Fitzherbert Science Centre, Batchelar Road, Palmerston North 4410, \\ New Zealand; trevor.jones@plantandfood.co.nz \\ * Correspondence: m.a.minor@massey.ac.nz; Tel.: +64-6-356-9099 (ext. 84833)
}

Received: 30 June 2020; Accepted: 19 July 2020; Published: 22 July 2020

check for updates

\begin{abstract}
Infestation of willow plants by the giant willow aphid Tuberolachnus salignus (Hemiptera: Aphididae) is associated with copious deposition of sugar-rich honeydew under the plant canopy. We explored the effect of aphid honeydew on the soil biota and biochemical indicators in a two-year field trial. Soil samples from under aphid-infested and control willow trees, as well as samples from black sooty mould spots under the aphid-infested willows were compared; soil samples before aphid inoculation were used as a baseline. The honeydew deposition had a positive effect on the total soil carbon (C), but not on the total soil nitrogen content or soil $\mathrm{pH}$. Microbial biomass $\mathrm{C}$, basal respiration, number of yeast colony forming units, and the geometric mean of activities for six enzymes were significantly higher in honeydew-affected soils than in the control treatment on both years. The honeydew deposition also increased soil meso-fauna abundance, especially in the black sooty mould spots. The soil biochemical properties, which differed before and after aphid infestation, showed considerable overlap between the first and second year post-infestation. The results highlight the cascading effects of T. salignus on soil biological activity and the importance of using a multitrophic approach to explore similar scenarios.
\end{abstract}

Keywords: Tuberolachnus salignus; honeydew; soil biochemical indicators; soil enzymes; yeasts; meso-fauna

\section{Introduction}

The giant willow aphid, Tuberolachnus salignus (Gmelin) (Hemiptera: Aphididae), is an invasive stem-feeding pest of willow trees, which has recently arrived in New Zealand [1]. Willows (Salix spp.) are important multi-purpose farm trees used for biomass production, bioremediation, erosion control, and soil nutrient management [2,3]. As T. salignus is a new species in New Zealand, not much is known about the ecological consequences associated with its presence in willow growing systems, such as its effects on the soil biota.

One of the prominent features of infested willow plantings is the deposition of copious amounts of honeydew by aphid colonies, and the growth of black sooty mould on the leaves, stems, and on the soil surface ([1]; see also Figure 1). A single adult T. salignus can exude $1.71-2.08 \mathrm{~mm}^{3}$ of honeydew per hour $[4,5]$. Chemically, the honeydew is a mixture of water, carbohydrates (90-95\% dry weight), amino acids $(<5 \%)$, lipids and other nutrients $[6,7]$. When this energy-rich liquid is deposited on the leaves and understory plants, it is splashed onto the soil surface by rainfall [8]. It can be hypothesized 
that deposition of T. salignus honeydew on the soil surface will initiate a cascade of changes in soil processes, causing modifications in soil chemical properties, microbial activities and in the abundance of soil microbivores. Previous studies have linked the labile carbon (C) input from aboveground aphid herbivory to changes in belowground biochemical properties [9-12]. These effects are linked to aphid population density [13] and the identity of the aphid species [14].

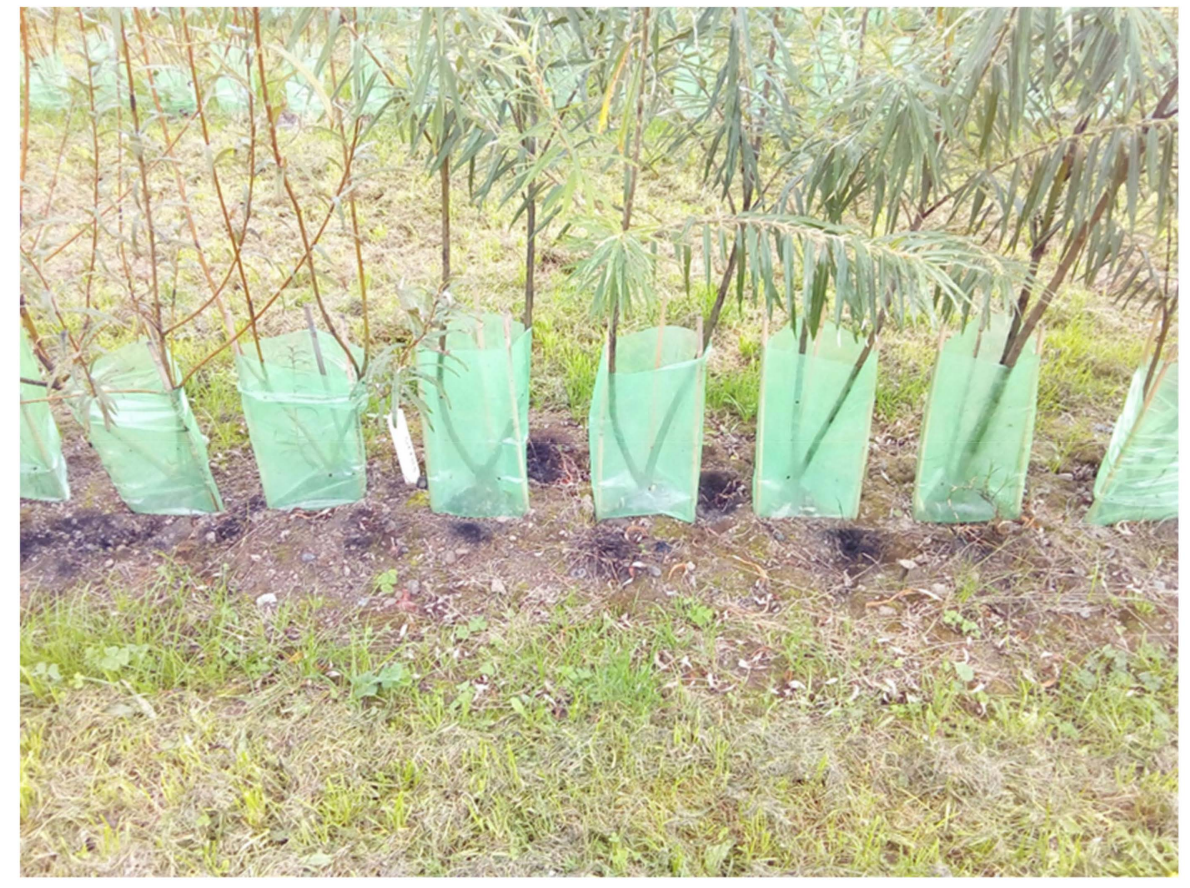

Figure 1. Black sooty mould spots under the canopy of willow plants.

Aphid honeydew deposition on the soil surface is expected to increase nutrient availability, fuel the growth of microbial communities in belowground systems [11,15], and influence the soil decomposition processes [16,17]. Microorganisms (bacteria, fungi, and other taxa) contribute to the functioning of soil ecosystems [18], regulating the processes of organic matter decomposition and nutrient cycling [19]. Soil microorganisms are assumed to be energy-limited, and as a result, mostly remain dormant when $\mathrm{C}$ resources are scarce [20]. The daily addition of sugar to the soil can cause a 2.5-fold increase in bacterial diversity, compared to control treatments, as sugar supplementation encourages the soil microbes to become active [21]. Aphid honeydew is a suitable growing medium for various saprophytic microbes [22] and has been shown to increase the activities of soil microorganisms [11,16]. Among soil microbes, yeasts are important degraders and saprotrophs $[23,24]$, utilizing various $\mathrm{C}$ and nitrogen $(\mathrm{N})$ sources [25]. Soil yeasts are ubiquitously present in many agroecosystems [26] and in nutrient-rich forest environments [23], and exhibit a quick response to changes in soil nutrient content [27].

Changes in soil microbial activity can also be reflected in the activities of soil enzymes [28]. Soil enzymes activity is a commonly used soil bioindicator [29], because of their quick response to subtle changes in available resources such as organic C input [30,31], and the ease of enzyme quantification [32]. So far, soil enzyme activities have not been used to explore honeydew-mediated changes in soil quality. Measuring the changes in the activities of soil enzymes following aphid infestation can provide a good tool to quantify the soil microbial responses to honeydew deposition $[19,33]$.

An increase in microbial biomass could have potential consequences for soil meso-fauna, as their abundance is likely to be affected through food web interactions [14,34]. Soil meso-fauna (Collembola and Acari) live in top soil layers and play different functional roles in soil processes and nutrient cycling [35]. Collembola, Astigmata, and Oribatida are dominant soil microbivores [36-41], while Gamasida are mobile predators of meso-fauna [42]. Although some studies have been conducted 
to explore the effect of honeydew deposition on soil meso-fauna abundance [14,34], the results are inconclusive as both increases and decreases in meso-fauna abundance have been reported in honeydew-affected soils.

The aim of this study was to investigate the cascading effects of honeydew deposition by T. salignus on soil chemical properties ( $\mathrm{pH}, \mathrm{C}$ and $\mathrm{N}$ ), soil microbial biomass and basal respiration, soil yeasts, abundance of soil meso-fauna (Acari and Collembola), and soil enzyme activity. Six enzymes were selected based on their sensitivities and importance in the electron transport system (dehydrogenase), cycling of C (glucosidase, invertase and amylase), and $\mathrm{N}$ (amidase and urease) in the soil. We analysed and compared soil biochemical properties and biota under control plants, under aphid-infested plants and in black sooty mould spots under aphid-infested plants.

\section{Materials and Methods}

\subsection{Willow Field Trial}

A willow field trial with an area of $4000 \mathrm{~m}^{2}(50 \mathrm{~m} \times 80 \mathrm{~m})$ was established at the Orchard Block, Plant Growth Unit, Massey University, Palmerston North, New Zealand $\left(40^{\circ} 22^{\prime} 41.70^{\prime \prime}\right.$ S, $175^{\circ} 36^{\prime} 30.67^{\prime \prime} \mathrm{E}, 30 \mathrm{~m}$ a.s.l). Average annual rainfall at the study site is $980 \mathrm{~mm}$, ranging from $64 \mathrm{~mm}$ in the driest month (February) to $99 \mathrm{~mm}$ in the wettest month (July). Average annual temperature is $13.3^{\circ} \mathrm{C}$, fluctuating from 8.6 (July) to $18.1^{\circ} \mathrm{C}$ (February) [43]. The soil type in the experimental area is a Manawatu fine sandy loam (Weathered Fluvial Recent Soil; [44]). Prior to planting willows, weeds were killed with glyphosate herbicide on 16 May 2017 and on 25 May 2017 the soil was rotary hoed in six rows. Each row was $1 \mathrm{~m}$ wide and $75 \mathrm{~m}$ long, with $4.0 \mathrm{~m}$ spacing between rows. The field trial was arranged in a split-plot layout, with three replicated blocks. Each block included two rows of willows; each row contained row plots of 12 ramets of fifteen willow cultivars. Willow cuttings $(20 \mathrm{~cm}$ in length and $13 \pm 2.6 \mathrm{~mm}$ in diameter) were planted on 16 June 2017, with $0.4 \mathrm{~m}$ spacing between cuttings within rows. After planting, the weeds were controlled by manual weeding and by spraying with Buster ${ }^{\circledR}$ herbicide. The two treatments, presence of $T$. salignus and aphid-free control, were randomly allocated to the two rows within each block.

\subsection{Aphids}

Willow plants in the aphid-infested rows were inoculated with five adult aphids per plant on 25-27 January 2018 and 6-7 December 2019. Additional inoculations with ten adult aphids per plant were performed on 13-14 February 2018 and 30 January 2019. The willow plants in the control rows were inspected for colonising aphids on a weekly basis, and any aphids found were removed manually. The plants in control rows were sprayed with Mavrik ${ }^{\circledR}$ insecticide on 28 February 2018 and on 17 January 2019, when manual control was impractical due to high population densities of T. salignus.

\subsection{Soil Sampling}

Soil samples were collected on the willow field trial site on 16 May 2017 prior to willow planting to assess spatial heterogeneity of the site. Following willow planting, samples were collected under the canopy of willow plants, in the $1.0 \mathrm{~m}$ wide cultivation zone, before aphid inoculation on 24 January 2018, after aphid inoculation on 22 June 2018, and on 2 July 2019. Three sampling points that were $20 \mathrm{~m}$ equidistant from each other, were marked along each of the six rows of the field trial (Figure S1).

Eighteen samples (one per sampling point), consisting of nine replicates from the aphid-infested and control rows, were collected during each sampling visit. Although all the plants in infested rows were inoculated with aphids, the honeydew was unevenly deposited, reflecting the distribution pattern of the aphid colonies. Therefore, additional soil samples were taken from black sooty mould spots (Figure 1) on the soil surface in the aphid-infested rows. Three samples (one per row) were collected on 22 June 2018, and six samples (two per row) were collected on 2 July 2019. Soil moisture content 
was measured three times at each sampling point using a TDR 300 Soil Moisture Probe (Spectrum Technologies Inc., Aurora, IL, USA), and the average of the three readings was then recorded. Soil temperature at $5 \mathrm{~cm}$ depth was measured with a QM7216 Digital Stem Thermometer. At each sampling point, two samples were collected, one for soil fauna extraction and another for analysing the soil chemical properties, microbial respiration and enzyme activities. The samples were put into labelled plastic bags, placed in an ice chest and immediately brought to the laboratory.

The samples used to quantify the soil meso-fauna (Collembola and Acari) were taken using a $25 \mathrm{~cm}^{2}$ soil corer to $5 \mathrm{~cm}$ depth. The sample (300-500 g) for soil chemical properties, microorganisms and enzymes was collected using a spade to $5 \mathrm{~cm}$ depth from five spots within a $1.0 \mathrm{~m}$ diameter circle around each sampling point, and then mixed thoroughly in a plastic tray to get a homogenous sample. Earthworms, plant roots, moss, stones, and other debris were removed before sieving the soil through a $2 \mathrm{~mm}$ drum sieve. The sieved soil was then divided into two subsamples. The subsample for analysing the soil chemical properties and enzyme activities was air-dried at room temperature, ground and sieved through a $1 \mathrm{~mm}$ mesh drum sieve. The subsample for determining the yeast colony forming unit (CFU), microbial respiration and biomass was frozen at $-20{ }^{\circ} \mathrm{C}$.

\subsubsection{Soil Chemical Properties}

The soil $\mathrm{pH}$ was measured in a slurry containing $5 \mathrm{~g}$ of soil and $12.5 \mathrm{~mL}$ of distilled water, using an Orion Star ${ }^{\mathrm{TM}}$ A214 pH/ISE Benchtop Meter (Thermo Scientific, Waltham, MA, USA). The total C and $\mathrm{N}$ content were determined by Vario Macro Cube (Elementar Analysensysteme GmbH, Langenselbold, Germany) from the mixture of soil (75-100 mg) and tungsten oxide powder (25-50 mg).

\subsubsection{Soil Fauna}

The soil samples for meso-fauna extraction were processed within $24 \mathrm{~h}$. The fauna were extracted from the soil cores using a modified Berlese-Tullgren apparatus, as described by Oliver and Beattie [45]. Extraction was performed under $15 \mathrm{~W}$ light bulbs (Sylvania, OH, USA, 240-250 W) in a 17 to $30^{\circ} \mathrm{C}$ temperature gradient in a temperature-controlled room for 7 days. The animals were collected into 70\% ethanol and examined using an Olympus SZX12 stereomicroscope (Spach Optics Inc., Rochester, NY, USA). The Collembola were identified to an order level. The soil Acari were assigned to three suborders: Oribatida, Astigmata and Gamasida. The other meso- and macro-fauna, including small insects, spiders, centipedes, Isopoda, Diplura, Symphyla, annelid worms and Pauropoda, were grouped as "others". The densities of the fauna were expressed as the number of individuals per $\mathrm{m}^{2}$.

\subsubsection{Soil Enzymes}

The urease (EC 3.5.1.5), invertase (EC 3.2.1.26), $\beta$-amylase (EC 3.2.1.2), $\alpha$-glucosidase (EC 3.2.1.20), dehydrogenase (EC 1.1.1.1) and amidase (EC 3.5.1.4) activities were assessed according to the protocols developed by Shcherbakova [46], Frankenberger and Johanson [47], Ross [48], Mfombep and Senwo [49], Serra-Wittling, et al. [50], Alef and Nannipieri [51] and Frankenberger [52], with slight modifications. Moist soil ( $1 \mathrm{~g}$ dry weight equivalent) was treated with $1.6 \mathrm{~mL}$ of triphenyltetrazolium chloride (TTC) before incubating at $30^{\circ} \mathrm{C}$ for $24 \mathrm{~h} ; 5 \mathrm{~mL}$ of acetone was added followed by incubation in the dark for $2 \mathrm{~h}$ to measure the dehydrogenase activity [51]. After incubating $0.25 \mathrm{~g}$ of soil with $2 \mathrm{~mL}$ of urea in phosphate buffer, and $20 \mu \mathrm{L}$ of toluene at $37^{\circ} \mathrm{C}$ for $4 \mathrm{~h}$, the urease activity was assayed using a Genova Nano Micro-Spectrophotometer (Jenway, Stone, Staffordshire, UK) as the amount of nitrate released from urea [46]. The amidase activity was assessed using formamide substrate, and the amount of ammonia released during hydrolysis of the enzyme was measured at a wavelength of $400 \mathrm{~nm}$ in the above-mentioned spectrophotometer [52]. The invertase activity was estimated by measuring the amount of glucose and fructose released from sucrose, after incubating soil samples ( $0.3 \mathrm{~g})$ with toluene and modified universal buffer at $\mathrm{pH} 5$ [47]. The amylase activity was measured using starch solution as a substrate, according to Wainwright, et al. [53]. Determination of the $\alpha$-glucosidase consisted of incubating soil samples $(1 \mathrm{~g})$ with toluene $(0.2 \mathrm{~mL}), 67 \mathrm{mM}$ sodium acetate buffer $(4.3 \mathrm{~mL}, \mathrm{pH} 5.0)$ and 
$50 \mathrm{mM}$ maltose $(0.5 \mathrm{~mL})$ in plastic tubes at $37^{\circ} \mathrm{C}$ for $1 \mathrm{~h}$; the activity of this enzyme was assayed after placing the tubes in a boiling water bath for $5 \mathrm{~min}$ [49]. The activity of each enzyme was expressed based on $1 \mathrm{~g}$ of dry soil. One gram of each fresh soil sample was used to estimate the dry-weight equivalent conversion factor. The samples were oven-dried at $80^{\circ} \mathrm{C}$ for $72 \mathrm{~h}$ until constant weight was achieved, and the dry weight measured.

The geometric mean of the enzyme activities (GMea) is regarded as a sensitive indicator for soil quality and soil health assessment [54-56]. The GMea calculation is based on the activities of all the assayed enzymes [54], and it is a more reliable index than any of the specific enzyme activities alone [57]. In this study, the GMea for six enzyme activities in the aphid-infested and control rows, and the black sooty mould soil spots was calculated according to Paz-Ferreiro, et al. [57] as follows:

$$
\text { the GMea }=\sqrt[6]{\text { Ure } \times \text { Inv } \times \text { Amy } \times \text { Glu } \times \text { Dehy } \times \text { Ami }}
$$

where Ure, Inv, Amy, Glu, Dehy and Ami represent urease, invertase, $\beta$-amylase, $\alpha$-glucosidase, dehydrogenease and amidase, respectively.

\subsubsection{Yeasts}

The frozen soil samples were incubated at $25{ }^{\circ} \mathrm{C}$ for $24 \mathrm{~h}$. Fresh soil was divided into three plastic tubes ( $1 \mathrm{~g}$ dry soil equivalent each), and suspended in Milli $\mathrm{Q}$ water to obtain three dilutions $(v / w, 1: 5,1: 10$ and 1:20) according to Yurkov, et al. [58]. After shaking the suspensions on an orbital shaker for $1 \mathrm{~h}, 0.1 \mathrm{~mL}$ aliquots were plated in triplicate on casein-peptone glucose yeast extract agar, supplemented with chloramphenicol $\left(0.1 \mathrm{~g} \mathrm{~L}^{-1}\right)$. Lactic acid was added to acidify the medium to $\mathrm{pH}$ 4.5. The plates were incubated at $25^{\circ} \mathrm{C}$ for 2 days and then transferred to a chiller $\left(5^{\circ} \mathrm{C}\right)$ to prevent mould development. Visible colonies were counted weekly for three consecutive weeks. The yeast counts were expressed as the colony forming units (CFU) per $1 \mathrm{~g}$ of dry soil, multiplied by the dilution factor $(5,10$ and 20$)$.

\subsubsection{Microbial Properties}

The microbial biomass $\mathrm{C}(\mathrm{Cmic})$ and basal respiration (BR) were determined by the substrate-induced respiration (SIR) method [59]. The frozen soil samples were incubated for $24 \mathrm{~h}$ at $25^{\circ} \mathrm{C}$. The samples ( $1 \mathrm{~g}$ dry weight equivalent) were weighed and placed into $22 \mathrm{~mL}$ glass vials. After dropwise addition of $0.1 \mathrm{~mL}$ glucose solution ( $8 \mathrm{mg} \mathrm{g}^{-1}$ soil), the vials were closed with airtight lids containing a septum in the centre. The vials were incubated at $22{ }^{\circ} \mathrm{C}$ for $3-5 \mathrm{~h}$. Air samples were collected using a syringe, and then injected into the $\mathrm{CO}_{2}$ analyser (HP 3396 Series II Integrator, Hewlett Packard, Palo Alto, CA, USA). The Cmic ( $\mu \mathrm{g} \mathrm{C} \mathrm{g}{ }^{-1}$ soil) was calculated as: $\mathrm{Cmic}=\operatorname{SIR}\left(\mu \mathrm{LCO}_{2} \mathrm{~g}^{-1}\right.$ soil h$\left.^{-1}\right) \times 40.04+0.37$, according to Anderson and Domsch [60]. A similar procedure was used for determining the BR, but only $0.1 \mathrm{~mL}$ of water was added to the vials prior to the $24 \mathrm{~h}$ incubation period at $22{ }^{\circ} \mathrm{C}$. The BR of the soil samples was measured as $\mu \mathrm{g} \mathrm{CO}_{2}-\mathrm{C} \mathrm{g}^{-1}$ dry soil $\mathrm{h}^{-1}$. The microbial metabolic quotient $\left(\mathrm{qCO}_{2}\right)$ was calculated by dividing the BR by the Cmic, and expressed in $\mu \mathrm{g} \mathrm{CO}_{2}-\mathrm{C} \mathrm{mg}^{-1} \mathrm{Cmic} \mathrm{h}^{-1}$ [61].

\subsection{Data Analysis}

All analyses were performed in R version 3.5.1 [62]. A Shapiro-Wilk test was used to check whether the data distributions met the assumption of normality. Generalized linear models (GLMs) were used for analysis of the treatment effects on the soil chemical and microbial properties, and enzyme activities. The gamma distribution with log-link function was used for non-normally distributed variables, while the normally distributed data were fitted using the gaussian distribution with identity link. Count data (meso-fauna and yeast CFU counts) were analysed in the GLM using the Poisson and quasi-poisson error distributions. The GLMs were fitted separately for the two sampling times, after the willow plants were inoculated with aphids. The pre-treatment sampling on 24 January 2018, prior to the aphid inoculation, was used as the baseline measurement, but was not included in the 
analysis of the aphid infestation treatment vs. control. The library "multcomp" was used for multiple comparisons using Tukey's HSD test, whenever the GLM results showed global significant differences of the means. Full results of all GLM tests are provided in the Supplementary Table S1.

The principal component analysis-linear discriminant analysis (PCA-LDA) was used to visualise the data and maximize the treatment segregation [63,64]. All variables were square-root transformed, scaled, and centred (divided by their respective standard errors) to assure equal variance, before conducting the PCA-LDA [65]. First, the PCA was performed to produce the principal components (PCs) in the "FactoMineR" and "factoextra" packages. The first eight PCs together explained more than $80 \%$ of the variance in the data and were used in the linear discriminant analysis (LDA). The "caret", "MASS" and "tidyverse" packages [63] were used to perform LDA.

In the PCA-LDA evaluating the honeydew-related changes in the soil biochemical properties among the control, aphid-infested treatments, and black sooty mould spots, the baseline measurements (collected before aphid inoculation) were excluded, as the aphid absence on the plants meant no honeydew was deposited on the soil surface. In the PCA-LDA, which compared the selected soil indicators over time, the baseline measurements as well as data from first and second year after aphid inoculation were included. Soil temperature and moisture measurements were excluded from the time analysis to remove bias due to weather.

In the current study, the effect of the willow cultivars was excluded from consideration. Previous research had showed the total sugar content in the honeydew of T. salignus was not statistically different among the willow cultivars [66]. The soil samples were taken from under the canopies of the same willow cultivars, in the aphid-infested and control rows.

\subsection{Structural Equation Modelling}

Structural equation modelling (SEM) is a more reliable approach than univariate correlations and regressions, because it provides path coefficients to examine the multiple associations in a multi-layered system [67]. SEM was constructed to explore how honeydew deposition could influence soil biochemical processes and functions, and to quantify the relative contribution of the different variables, which form a network of causal relationships [68].

The a priori hypothetical model was first constructed to describe the causal relationships for the effects of aphid honeydew on the soil environment, linking T. salignus honeydew deposition to Cmic, specific enzyme activities, meso-fauna abundance, and the geometric mean of the enzyme activities (GMea). This was based on a modification of the path model constructed by Milcu, et al. [14]. Variables for the model were selected based on the PC scores (Figure S2) and previous literature. We then used SEM to calculate the coefficients associated with each path in SPSS Amos 25 (IBM, Armonk, NY, USA) [69].

The data on the soil analysis from the two sampling dates after aphid inoculation were pooled for this analysis; the pre-treatment data, prior to aphid inoculation, were excluded. The honeydew input was coded as a categorical (ordinal) variable, with 0 for control, 1 for aphid-infested, and 2 for black sooty mould spots. The $\mathrm{Cmic}$, total $\mathrm{C}$ and $\mathrm{N}$ contents were selected to evaluate the direct effect of honeydew deposition. The Cmic was chosen to estimate the indirect effect of honeydew deposition on the Gmea and meso-fauna abundance, as Cmic has been shown to associate with soil fauna [14], soil chemical properties (total C, total $\mathrm{N}$ ) and enzyme activities [70].

The critical ratio of the multivariate kurtosis and squared Mahalanobis distance were checked for multivariate normality and the presence of outliers [71]. The pooled dataset, containing the selected variables over the two sampling times, was square-root transformed to meet the assumption of multivariate normality. The maximum likelihood estimation was used to test the path coefficients in the SEM models. Standardized coefficients were calculated for all the variables in the paths diagram [72,73]. The Chi-square test, probability value of the likelihood ratio test, comparative fit index (CFI), root mean square error of approximation (RMSEA), and Akaike's information criterion (AIC) were used to evaluate the model fit. 


\section{Results}

\subsection{Soil Chemical Properties}

Before the willows were planted, the soil of the field trial site had a mean $\mathrm{pH}$ value of $6.1 \pm 0.05$, $2.4 \pm 0.08 \%$ total $\mathrm{C}$ and $0.25 \pm 0.01 \%$ total $\mathrm{N}$. None of these parameters exhibited any significant spatial differences prior to willow planting. The baseline measurements for soil chemical properties after planting prior to aphid infestation are included in Table 1.

Table 1. Soil chemical properties before aphid inoculation (baseline) and after aphid inoculation (control, aphid-infested and black sooty mould spots), during the first and second year of the experiment. Values are the means \pm SE. Different letters in each column indicate significant differences between the treatments at each sampling time (Tukey's HSD test, $\alpha=0.05$ ).

\begin{tabular}{|c|c|c|c|c|}
\hline \multirow[b]{2}{*}{ Parameter } & \multirow[b]{2}{*}{ Treatment } & \multicolumn{3}{|c|}{ Sampling Time } \\
\hline & & $\begin{array}{l}\text { Before Aphid } \\
\text { Infestation }\end{array}$ & First Year & Second Year \\
\hline \multirow{4}{*}{$\mathrm{pH}$} & Baseline & $5.75 \pm 0.03$ & & \\
\hline & Control & & $6.102 \pm 0.032 \mathrm{a}$ & $6.073 \pm 0.029 a$ \\
\hline & Aphid-infested & & $6.177 \pm 0.052 \mathrm{a}$ & $6.058 \pm 0.065 a$ \\
\hline & Black sooty mould spots & & $6.163 \pm 0.091 \mathrm{a}$ & $6.067 \pm 0.040 \mathrm{a}$ \\
\hline \multirow{4}{*}{ Total C (\%) } & Baseline & $2.40 \pm 0.06$ & & \\
\hline & Control & & $2.146 \pm 0.076 b$ & $2.278 \pm 0.110 \mathrm{~b}$ \\
\hline & Aphid-infested & & $2.260 \pm 0.061 b$ & $2.297 \pm 0.084 b$ \\
\hline & Black sooty mould spots & & $2.490 \pm 0.023 a$ & $2.547 \pm 0.070 \mathrm{a}$ \\
\hline \multirow{4}{*}{ Total N (\%) } & Baseline & $0.27 \pm 0.01$ & & \\
\hline & Control & & $0.238 \pm 0.006 a$ & $0.247 \pm 0.011 \mathrm{a}$ \\
\hline & Aphid-infested & & $0.249 \pm 0.005 a$ & $0.242 \pm 0.008 \mathrm{a}$ \\
\hline & Black sooty mould spots & & $0.237 \pm 0.009 a$ & $0.247 \pm 0.006 a$ \\
\hline \multirow{4}{*}{$\mathrm{C}: \mathrm{N}$} & Baseline & $8.79 \pm 0.13$ & & \\
\hline & Control & & $9.008 \pm 0.136 b$ & $9.207 \pm 0.178 b$ \\
\hline & Aphid-infested & & $9.076 \pm 0.107 \mathrm{~b}$ & $9.483 \pm 0.216 b$ \\
\hline & Black sooty mould spots & & $10.547 \pm 0.306 a$ & $10.302 \pm 0.140 \mathrm{a}$ \\
\hline
\end{tabular}

Honeydew deposition resulted in a higher total $C$ content in the black sooty mould spots compared to the control and aphid infestation treatments in both first and second year after aphid infestation (Table 1). There was no effect of the treatments on the soil $\mathrm{pH}$ values or total $\mathrm{N}$ content in both years. The C:N ratio was significantly higher in the black sooty mould spots in both years (Table 1).

\subsection{Soil Meso-Fauna}

Of the $4.80 \times 10^{6}$ soil meso-fauna collected in samples, Collembola was the most dominant taxon, comprising $75.5 \%$ of the total. Significantly higher Collembola densities were observed in the black sooty mould spots in the first year, and in both the aphid-infested rows and black sooty mould spots in the second year, compared to the control treatments (Figure 2a).

The soil Acari $\left(0.92 \times 10^{6}\right.$ individuals) accounted for $19.3 \%$ of the soil meso-fauna. Gamasida was the most abundant taxon, comprising $67.9 \%$ of the Acari. The aphid infestation had a significant effect on gamasid mites only in the first year, with higher densities in the black sooty mould spots (Figure 2b). Astigmata accounted for $19.3 \%$ of the total soil mites. Their densities were higher in the black sooty mould spots than the control and aphid infestation treatments in first year (Figure 2c). Oribatida was the least abundant group (12.8\%) of soil mites. In the second year, significantly higher densities of Oribatida were recorded in the black sooty mould spots than in aphid infestation treatment but not in the control treatment (Figure $2 \mathrm{~d}$ ). The black sooty mould spots also had higher population densities of the 'other' fauna in the second year (Figure 2e). 

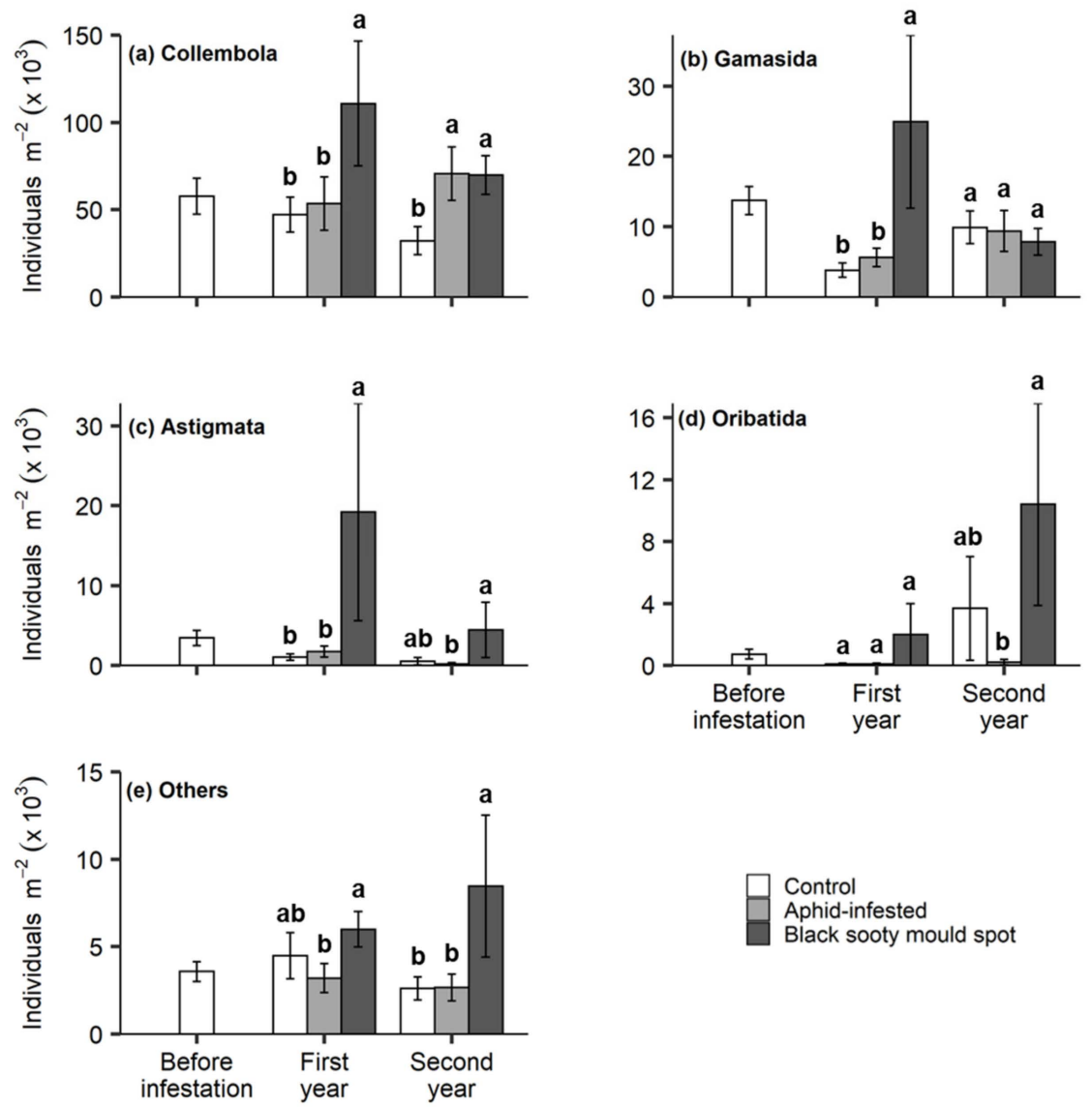

Figure 2. The effect of T. salignus honeydew deposition on the abundance of soil meso-fauna: Collembola (a), Gamasida (b), Astigmata (c), Oribatida (d) and others (e), prior to aphid inoculation (before infestation), and after aphid inoculation (control, aphid-infested, and black sooty mould spots) in the first and second year. The values are the means \pm SE. Different letters indicate statistically significant differences between treatments within each sampling time (Tukey's HSD test, $\alpha=0.05$ ).

\subsection{Soil Enzymes}

In general, honeydew deposition affected the soil enzyme activities, which tended to be higher in black sooty mould spots than in aphid-infested and control treatments (Figure 3). The dehydrogenase and $\beta$-amylase had significantly higher activities in the black sooty mould spots in both years; in the second year the activity of these enzymes was also higher in the aphid infestation treatment than in the control (Figure 3a,d). The soil urease activity was consistent across the two years and showed a significant response to honeydew deposition in the order: black sooty mould spots $>$ aphid-infested $>$ control (Figure $3 b$ ). Both the amidase and invertase had significantly higher activities in the black sooty mould spots in the first year; in the second year the trend remained, but the differences were not significant (Figure 3c,e). The activity of soil $\alpha$-glucosidase was significantly higher in black sooty mould spots than in the control treatment in both years, but there was no difference between the control and aphid-infested treatments (Figure 3f). Similar to the specific enzyme activities, the Gmea for the six enzymes was significantly influenced by the honeydew deposition; the Gmea in the first and second year was in the order: black sooty mould spots $>$ aphid-infested $>$ control (Figure 4). 

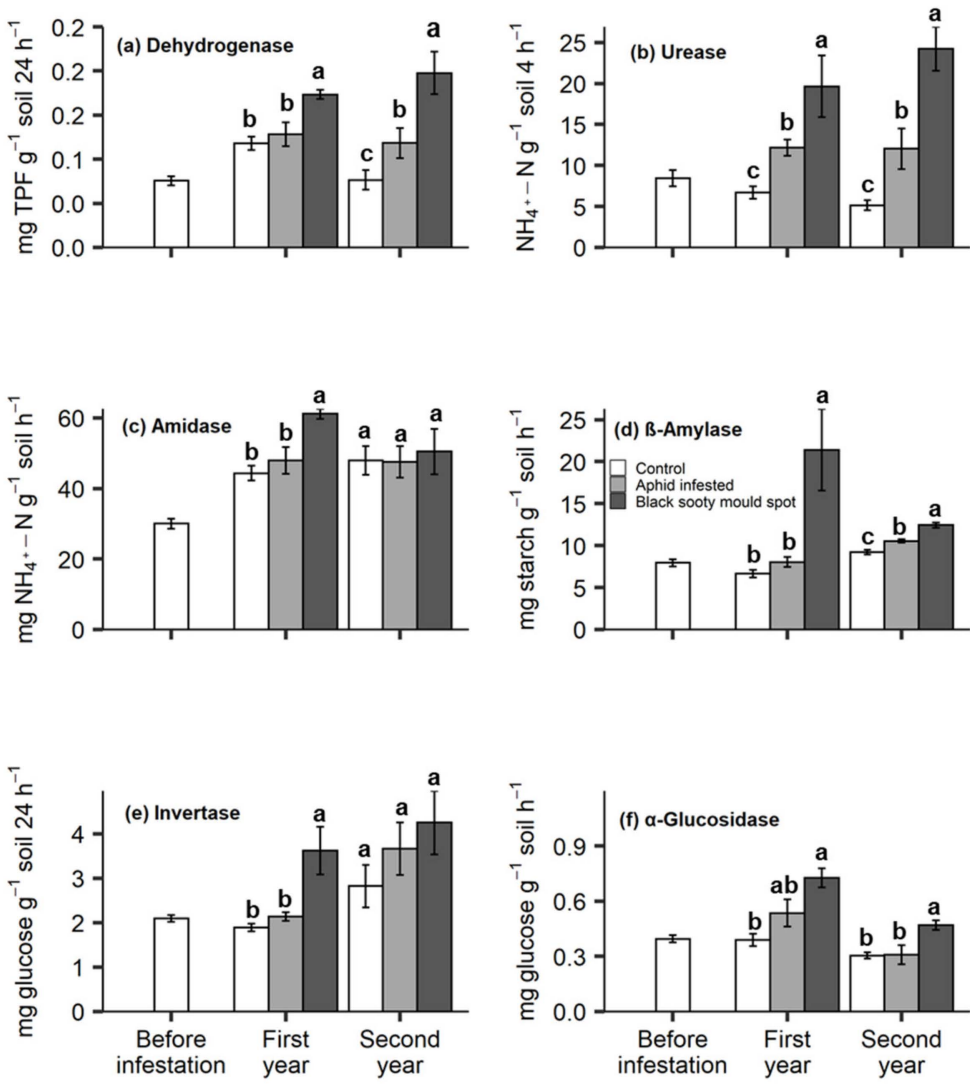

Figure 3. The activity of the soil enzymes: dehydrogenase (a), urease (b), amidase (c), $\beta$-amylase (d), invertase (e) and $\alpha$-glucosidase (f) under the canopies of willow plants, prior to aphid inoculation (before infestation), and after aphid inoculation (control, aphid-infested, and black sooty mould spots) in the first and second year. The values are the means \pm SE. Different letters indicate significant differences between the treatments at each sampling time (Tukey's HSD test, $\alpha=0.05$ ).

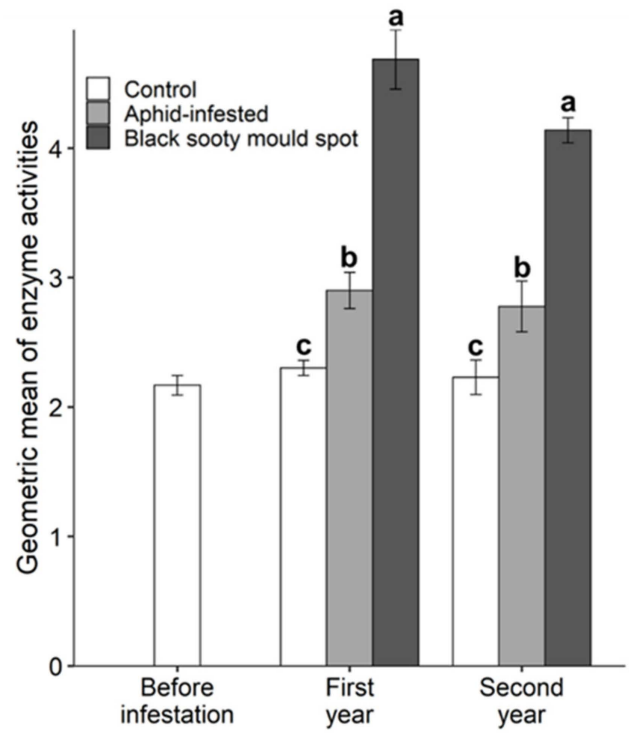

Figure 4. The effect of T. salignus honeydew deposition on the geometric mean of soil enzyme activities, prior to aphid inoculation (before infestation), and after aphid inoculation (control, aphid-infested, and black sooty mould spots) in the first and second year. The values are the mean \pm SE. Different letters represent statistically significant differences between the treatments at each sampling time (Tukey's HSD test, $\alpha=0.05)$. 


\subsection{Soil Microbial Properties and Yeast CFU}

In both years, soil Cmic (Figure 5a), basal respiration (Figure 5b) and yeast CFU (Figure 6) increased in the order: control > aphid-infested > sooty mould spots, with all differences being significant. The microbial quotient $\left(\mathrm{qCO}_{2}\right)$ was significantly higher in the black sooty mould spots than in the aphid-infested and control treatments only in the second year (Figure 5c).
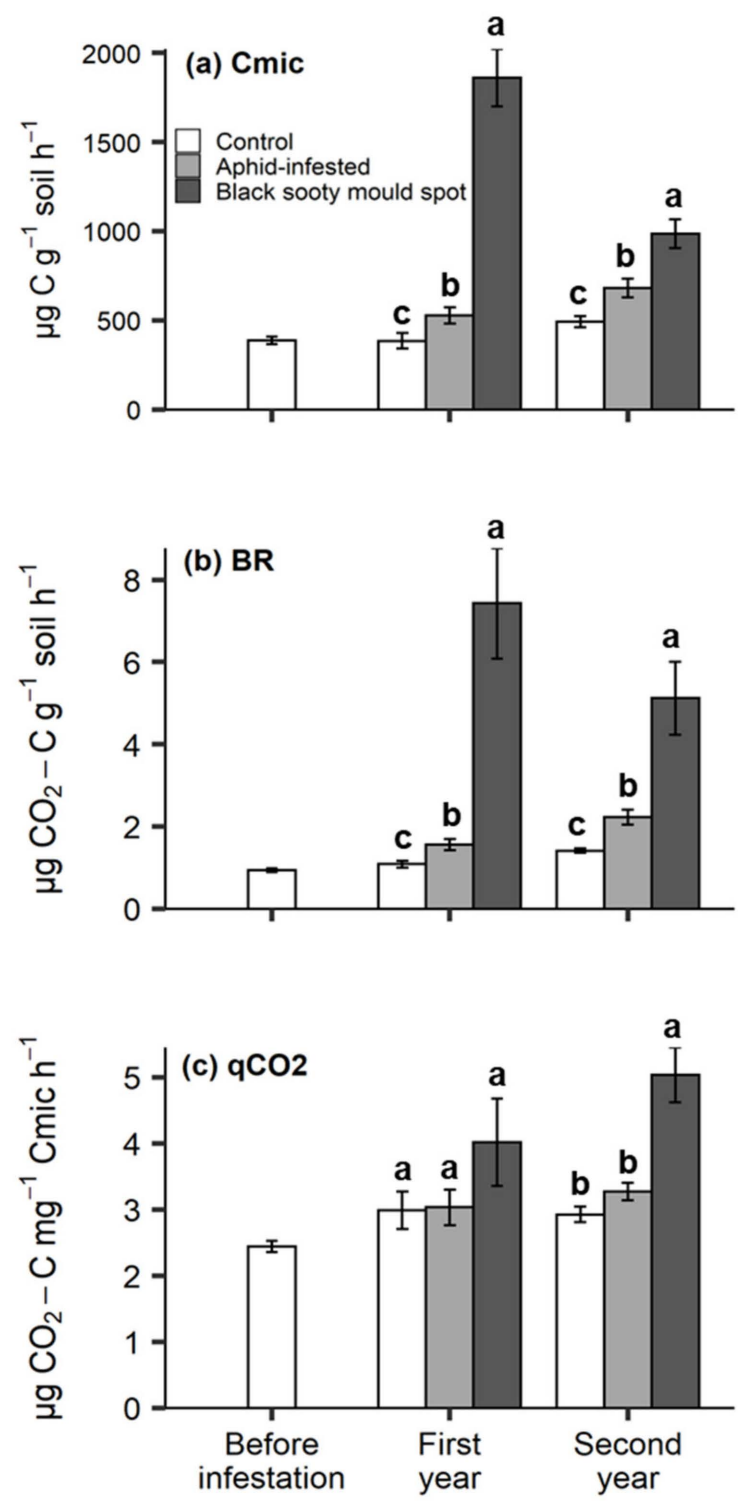

Figure 5. The effect of T. salignus honeydew deposition on (a) soil microbial biomass ( $\mu \mathrm{g} \mathrm{C} \mathrm{g}{ }^{-1}$ soil), (b) basal respiration $\left(\mu \mathrm{g} \mathrm{CO} \mathrm{CO}_{2}-\mathrm{C} \mathrm{g}^{-1}\right.$ soil h$\left.{ }^{-1}\right)$, and (c) metabolic quotient over time $\left(\mu \mathrm{g} \mathrm{CO} \mathrm{CO}_{2}-\mathrm{C}^{-1}\right.$ $\mathrm{Cmic}^{-1}$ ), prior to aphid inoculation (before infestation), and after aphid inoculation (control, aphid-infested, and black sooty mould spots) in the first and second year. The values are the means \pm SE. Different letters indicate statistically significant differences at each sampling time (Tukey's HSD test, $\alpha=0.05)$. 


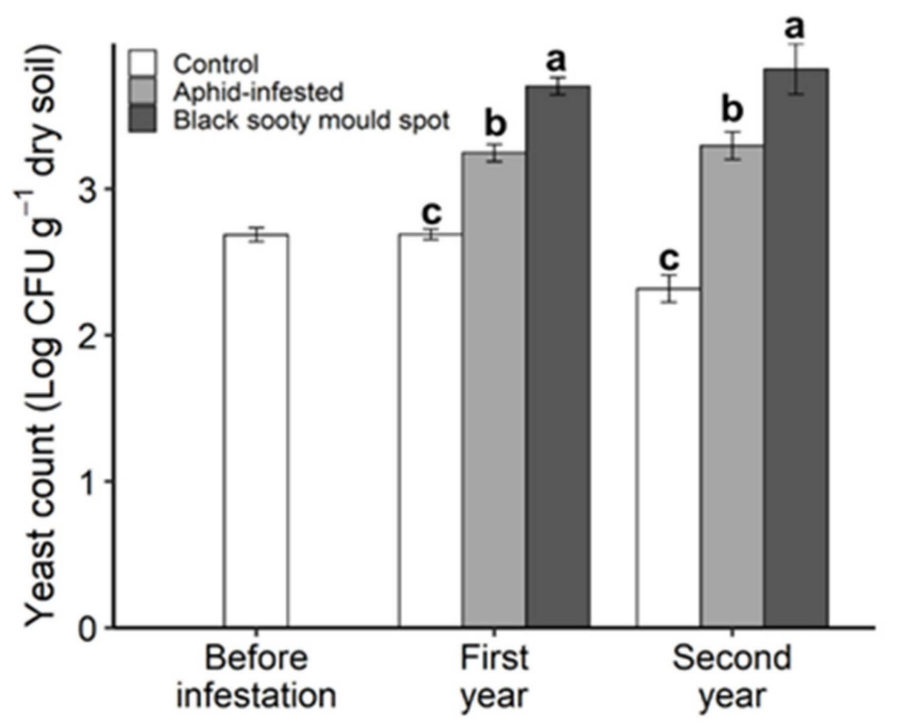

Figure 6. The yeast colony forming units (CFU) per gram of dry soil, collected under the canopies of willow plants prior to aphid inoculation (before infestation), and after aphid inoculation (control, aphid-infested, and black sooty mould spots) in the first and second year. The values are the means \pm SE. Different letters indicate statistically significant differences at each sampling time (Tukey's HSD test, $\alpha=0.05$ ).

\subsection{Principal Component Analysis-Linear Discriminant Analysis (PCA-LDA)}

The PCA-LDA showed the localized effect of the honeydew deposition in the black sooty mould spots, and the change after aphid infestation (Figure 7).

The first PCA-LDA clearly separated the black sooty mould spots from the other two treatments, but there was some overlap between the control and the aphid-infested treatment (Figure 7a). For the three treatments, the first (LD1) and second (LD2) discriminant functions explained 95.8 and $4.2 \%$ of the total variability, respectively. The GMea, $\mathrm{BR}, \mathrm{Cmic}, \mathrm{C}: \mathrm{N}$ ratio, urease, $\beta$-amylase, $\mathrm{qCO}_{2}$, and yeast $\mathrm{CFU}$ were the variables that contributed the most to the separations along the PC1 (Figure S2a), which had the highest discriminant coefficient in the first linear discriminant (LD1).

The second PCA-LDA clearly separated the sampling times prior to aphid inoculation (before aphid infestation), and after aphid inoculation in the first and second years, but there was considerable overlap between the first and second year post-infestation (Figure 7b). The GMea, BR, Cmic, C:N ratio, urease, $\beta$-amylase, $\mathrm{qCO}_{2}$, and yeast $\mathrm{CFU}$ were also the variables that contributed the most to the separation along PC1 (Figure S2b) which had highest weight in separating sampling times in LD1 $(84.9 \%$ of the total variability) (Figure $7 \mathrm{~b})$. 

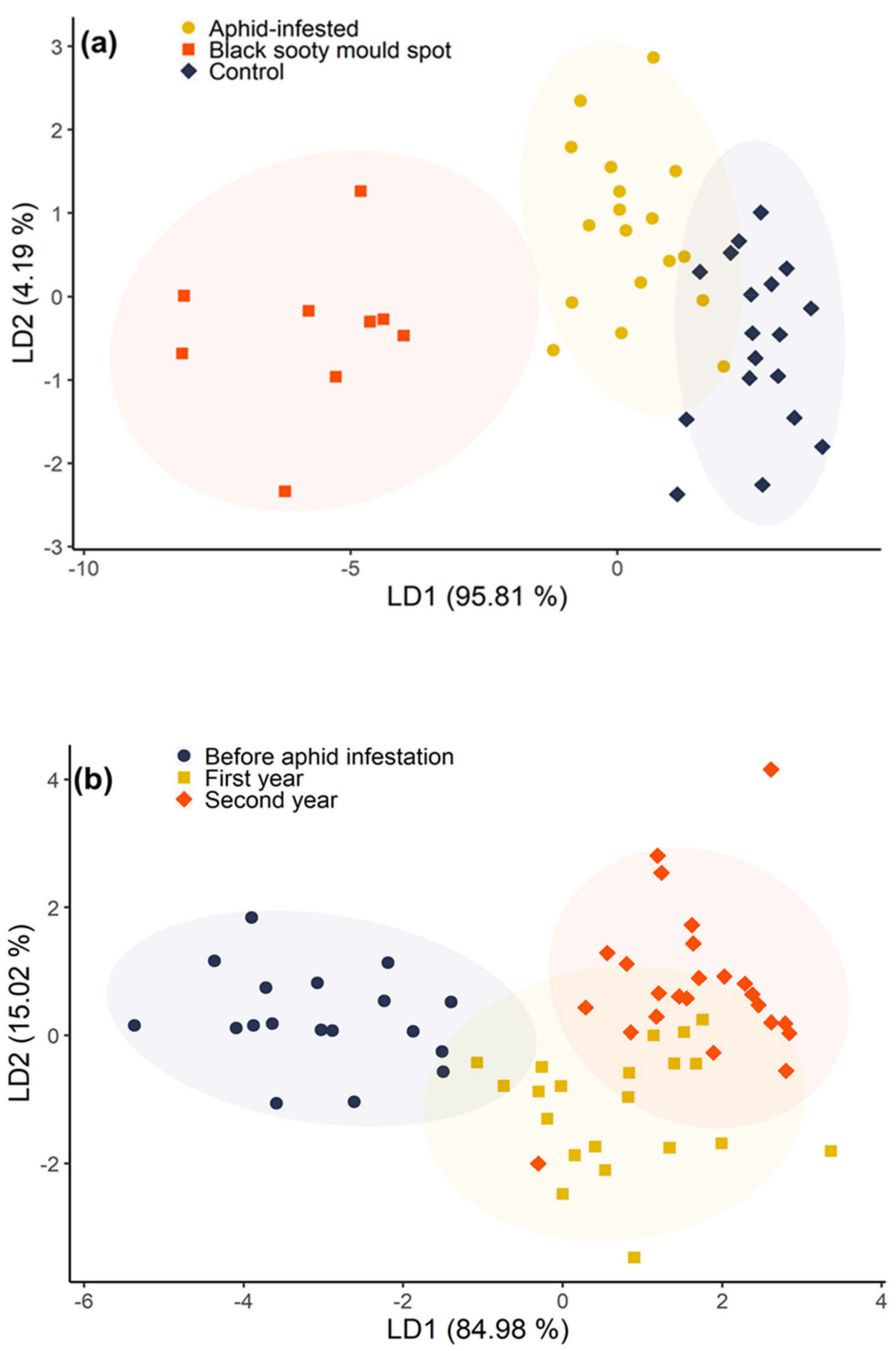

Figure 7. PCA-LDA bi-plots of the soil biochemical variables, classified (a) by treatment, and (b) by sampling time. A PCA was run to reduce the dimensions, followed by LDA to separate the treatments and sampling times. The variables were scaled and centred prior to the analysis. The shaded ellipses represent the $95 \%$ confidence areas.

\subsection{Structural Equation Modelling (SEM)}

The SEM for the soil enzymatic response revealed a fairly good fit to the data $\left(\chi^{2}=125.7\right.$, $\left.\mathrm{df}_{(66-28)}=38, p<0.001, \mathrm{RMSEA}=0.00, \mathrm{CFI}=1, \mathrm{AIC}=181.7\right)$. The honeydew deposition had a positive direct effect on the total soil $\mathrm{C}$ and microbial biomass $\mathrm{C}$ (Cmic), but not on the total $\mathrm{N}$ (Figure $8 \mathrm{a}$ ). Total soil $\mathrm{C}$ also increased the $\mathrm{Cmic}$, while the total $\mathrm{N}$ had significant negative effect on $\mathrm{Cmic}$. The $\mathrm{Cmic}$ 
increased the activities of all six assayed enzymes (Figure 8a), but the degree of influence was largest for $\beta$-amylase, urease, and dehydrogenase. The increased activities of urease, $\alpha$-glucosidase and invertase contributed most to the geometric mean of the enzyme activities (GMea).

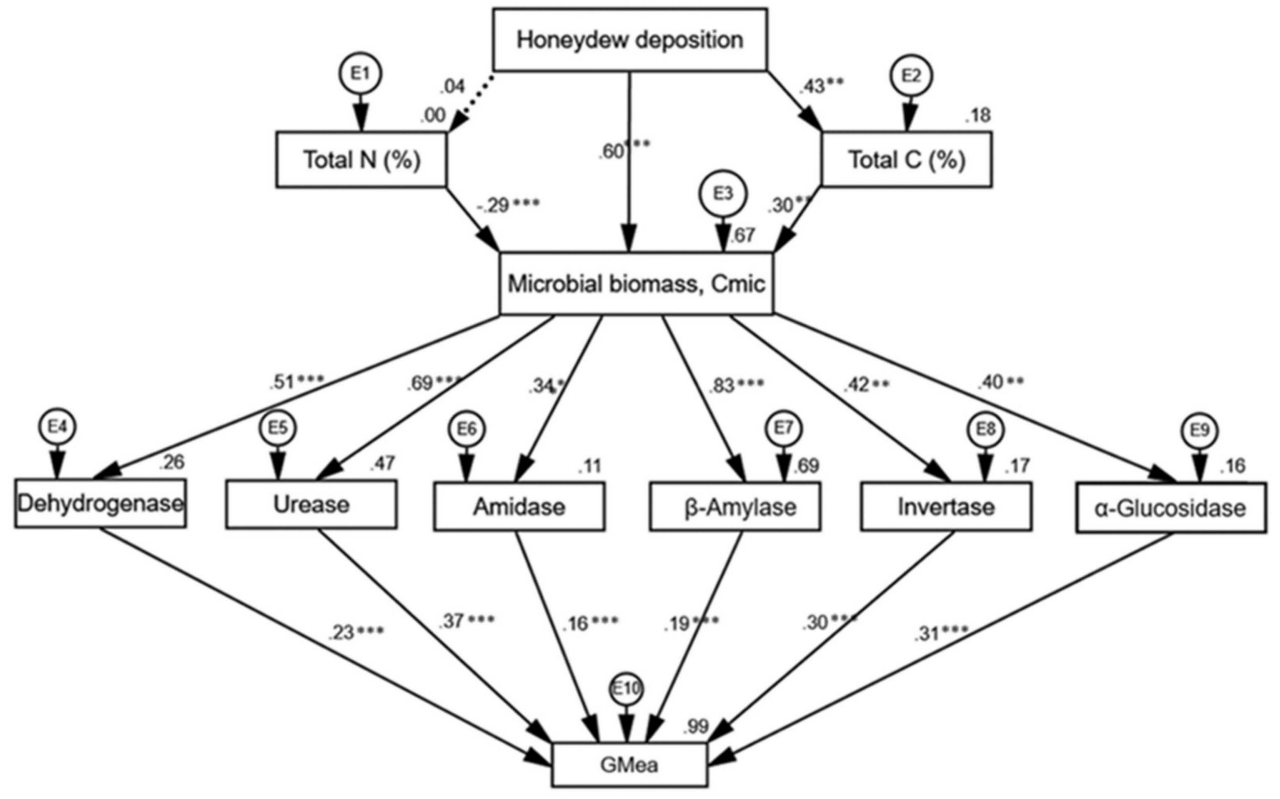

(a)

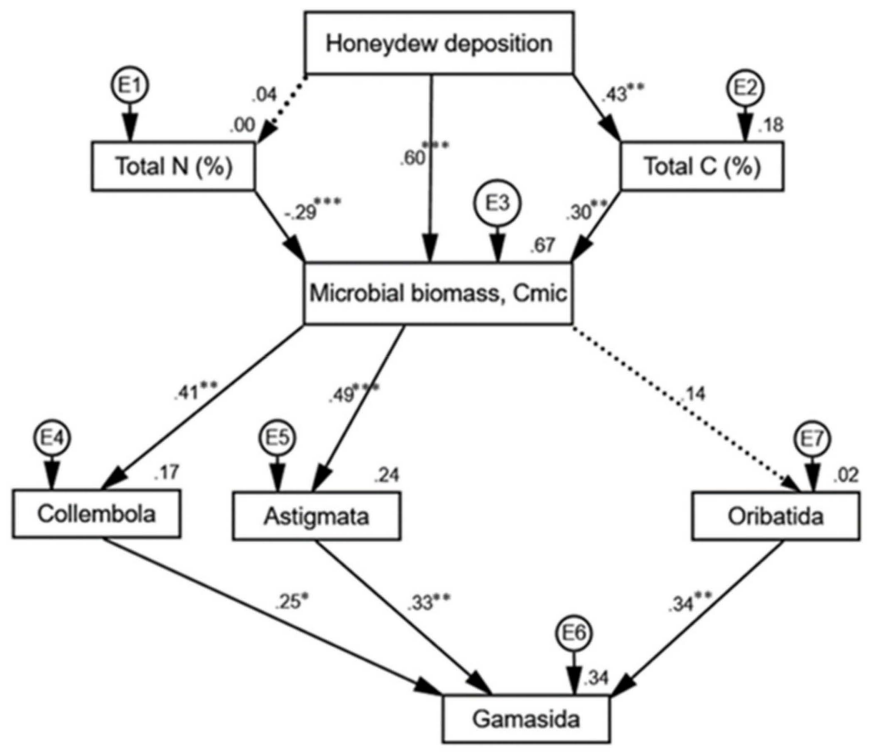

(b)

Figure 8. Path diagrams for the effects of T. salignus honeydew deposition on (a) soil biochemical properties, and (b) meso-fauna communities. The circles above the rectangles indicate the error terms. The solid and dotted arrows represent significant and non-significant associations, respectively. The path coefficients are the standard regression weights, with asterisks showing different levels of significance $\left({ }^{*} p<0.05,{ }^{* *} p<0.01,{ }^{* * *} p<0.001\right)$. The squared multiple correlations $\left(\mathrm{r}^{2}\right)$ are expressed above the top right corner of each rectangle. 
The SEM for the soil meso-fauna abundance had a better fit to the data $\left(\chi^{2}=87.3, \mathrm{df}_{(36-19)}=17\right.$, $p<0.001$, RMSEA $=0.00, \mathrm{CFI}=1$, AIC = 72.0). The honeydew deposition increased the Cmic, which increased the abundance of the Collembola and Astigmata, but no significant effect was found for Oribatida mites (Figure $8 b$ ). The abundance of Gamasida was positively correlated with the abundance of their prey-Collembola, Astigmata and Oribatida.

\section{Discussion}

In the willow field trial, the development of black sooty mould spots on the soil surface (Figure 1) is an indication of a high population density of T. salignus. As expected, we found that the copious deposition of honeydew on the soil surface affected the soil biological and biochemical properties, especially in the spots marked by the black sooty mould. Overall, the soil biological indicators (microbial properties, enzyme activities and meso-fauna abundance) were found to be more sensitive to aphid honeydew deposition than the soil chemical properties.

In our study, T. salignus honeydew deposition increased the soil total C content but did not change soil total N content. Stadler, et al. [16] found that honeydew input increased the dissolved organic $\mathrm{C}$ in litter, but reduced inorganic $\mathrm{N}$ content, and suggested that net $\mathrm{N}$ immobilization had occurred. Aphid honeydew is a C-rich but N-poor resource [5], inducing the population of soil microorganisms to increase and then compete for the limited $\mathrm{N}$, which can increase the $\mathrm{N}$ immobilization rate and result in the depletion of inorganic $\mathrm{N}[16,74]$. Thus, the honeydew deposition could indirectly decrease the soil $\mathrm{N}$ content through enhanced microbial activity $[15,75]$, where microorganisms could emerge as potential competitors of willow plants for nitrogen resources [76]. However, there is some evidence that $\mathrm{N}$ limitations can be compensated through increased non-symbiotic $\mathrm{N}_{2}$-fixation by soil microorganisms [77].

The results of our study showed that sugar supplementation in the honeydew increased the yeast CFU count, microbial biomass $\mathrm{C}$ and microbial respiration. Soil microorganisms are mostly energy limited and remain dormant in the absence of a suitable substrate [20], so honeydew addition could increase their population numbers and respiration rate by promoting favourable growth conditions [78]. Soil yeasts prefer nutrient-rich environments and are known to utilize low molecular weight sugars [23] that are the major components of aphid honeydew. The increase in microbial biomass $C(\mathrm{Cmic})$ and basal respiration are in accordance with the study of Milcu, et al. [14], who found that Cmic and basal respiration increased by $330 \%$ and $58.4 \%$, respectively, in honeydew treatments. However, care should be taken in interpreting the microbial response to honeydew addition, as the sugar component of honeydew can shut down the metabolism of some microbes [79]. Further studies using molecular techniques are advised to determine the changes in the soil microbial community structure following honeydew deposition.

The activity of soil enzymes is regarded as a direct measurement of the metabolic response of the soil microbial communities to nutrient availability [28]. Our results show a significant effect of nutrient supplementation from aphid honeydew on the soil enzyme activities. Although honeydew contains an unbalanced ratio of $\mathrm{C}$ to $\mathrm{N}$, we found that both $\mathrm{C}$-hydrolysing ( $\beta$-amylase, invertase, $\alpha$-glucosidase), and N-hydrolysing (urease and amidase) enzymes positively responded to the honeydew deposition. Dehydrogenase was also found to be a sensitive indicator of increased microbial activity [80,81] as a result of the supplementary $C$ input from honeydew. The interpretation of enzyme activity results should be treated cautiously as enzyme assays generate the highest potential estimates, under optimum substrate, $\mathrm{pH}$ and temperature conditions, rather than the actual values [51]. However, both the specific enzyme activities and the GMea were suitable indicators discriminating the black sooty mould spots from the control, with GMea being the best predictor.

Soil meso-fauna (Collembola and Acari) normally live in the topsoil layers, and play different functional roles in the soil processes and nutrient cycling [35]. We observed that Collembola counts in the honeydew-affected soil were higher than in control. Sinka, et al. [34] found no significant influence of honeydew deposition on Collembola abundance, while Milcu, et al. [14] reported the decline in 
Collembola and mite numbers in soil treated with synthetic honeydew. Seeger and Filser [82] noted that the effect varied for different collembolan taxa. The mite groups Astigmata and Oribatida are fungivores and saprophages [83], while the Gamasida are predators of other soil mites and Collembola [84]. In our study, the abundance of Oribatida and Gamasida varied over time, while that of Astigmata was fairly consistent. All three mite groups are known to respond to external resources [85,86], with the degrees of response to the aphid honeydew reflecting their different life histories. The Astigmata are known for their rapid response to the changing environment, due to their faster metabolism, shorter generation time, and higher fecundity than the Oribatida [83]. On the other hand, the higher population density of Gamasida reflects the presence of the prey on which they feed [87].

The SEMs were a useful tool to assess the multiple linkages between the honeydew and the soil biological and biochemical indicators, linking the aboveground herbivory to the below-ground soil processes. The path diagrams show that honeydew deposition by T. salignus has a multitrophic cascading effect on the soil biota, similarly as in Michalzik, et al. [13], Milcu, et al. [14] and Stadler, et al. [88]. In the current study, the Cmic was positively correlated with the soil total C content, but not with the total N. Our results are in line with those of Cheng, et al. [70] and Johnson, et al. [89], who suggested that the Cmic was mainly dependent on the soil $\mathrm{C}$ source, and additional $\mathrm{N}$ input could decrease the Cmic.

In our study system, the willow plants, aphids, soil chemical properties and soil biota are interacting with each other, highlighting the need for a multitrophic approach to investigate similar settings. It is important to mention that this study was conducted over two years only, so the long-term effects of the honeydew deposition on the soil remain unknown and require further investigation. Likewise, the impacts of the other sources of variation, including the different insect and host plant species [14], weather conditions [90] and seasonality [91], require additional attention.

\section{Conclusions}

The deposition of T. salignus honeydew affect the various soil biotic and abiotic properties through a multitrophic cascade. The aphid honeydew provides an energy-rich source for the soil microbes, causing an increase in the $\mathrm{Cmic}$, that leads to increased soil enzyme activities. These processes affect the abundance of soil meso-fauna microbivores and their predators. This example illustrates the importance of multitrophic interactions, and the cascading effects of an aphid herbivore on soil chemical properties and soil biological communities.

Supplementary Materials: The following are available online at http://www.mdpi.com/2075-4450/11/8/460/s1, Figure S1: Sampling layout for the soil samples, Figure S2: Correlation plots for contributing variables to each dimension in the PCA for treatments (a), and sampling times (b), Table S1: Summary of treatment effects of T. salignus honeydew deposition on soil biochemical properties, soil enzymes, and soil meso-fauna abundance in first and second year of the experiment.

Author Contributions: Conceptualization, M.M., A.C.M. and T.J.; methodology, M.M., A.C.M., S.G. and K.M.T.; validation, M.M., A.C.M. and T.J.; formal analysis, K.M.T. and S.G.; investigation, M.M., K.M.T. and S.G.; resources, M.M., and S.G.; writing-original draft preparation, K.M.T.; writing-review and editing, S.G., M.M., A.C.M. and T.J.; visualisation, K.M.T.; supervision, M.M., A.C.M. and T.J.; project administration, M.M. All authors have read and agreed to the published version of the manuscript.

Funding: This was a part of PhD project funded by the New Zealand Government Scholarship to K.M.T.

Acknowledgments: The authors wish to acknowledge the contribution to the willow field trial from the Sustainable Farming Fund Project, Ministry for Primary Industries (MPI), New Zealand. Thanks also go to Evans Effah, Michelle Guerrero, Mari Nakano, Claire Zucchetta and Shaun Nelson for assisting in aphid inoculation and soil sampling. We thank Paul Barrett, Ian Furkert, Kay Sinclair, Sunmeet Bhatia, Sue Nicholson and Peter Jeffery for their assistance with laboratory work. We are also grateful to anonymous reviewers for improving the earlier draft of manuscript.

Conflicts of Interest: The authors declare no conflict of interest. 


\section{References}

1. Sopow, S.; Jones, T.; Mclvor, I.; McLean, J.; Pawson, S. Potential impacts of Tuberolachnus salignus (giant willow aphid) in New Zealand and options for control. Agr. Forest Entomol. 2017, 19, 225-234. [CrossRef]

2. McIvor, I. Willows for the Farm-Specially Selected for New Zealand Conditions; Plant and Food Research: New Zealand, 2013.

3. Smart, L.B.; Volk, T.A.; Lin, J.; Kopp, R.F.; Phillips, I.S.; Cameron, K.D.; White, E.A.; Abrahamson, L.P. Genetic improvement of shrub willow (Salix spp.) crops for bioenergy and environmental applications in the United States. Unasylva 2005, 221, 51-55.

4. Mittler, T.E. Studies on the feeding and nutrition of Tuberolachnus salignus(Gmelin) (Homoptera: Aphididae) I. The uptake of phloem sap. J. Exp. Bot. 1957, 34, 334-341.

5. Mittler, T.E. Studies on the feeding and nutrition of Tuberolachnus salignus (Gmelin) (Homoptera: Aphididae) III. The nitrogen economy. J. Exp. Biol. 1958, 35, 626-638.

6. Dhami, M.K.; Gardner-Gee, R.; Van Houtte, J.; Villas-Bôas, S.G.; Beggs, J.R. Species-specific chemical signatures in scale insect honeydew. J. Chem. Ecol. 2011, 37, 1231-1241. [CrossRef]

7. Byrne, D.N.; Miller, W.B. Carbohydrate and amino acid composition of phloem sap and honeydew produced by Bemisia tabaci. J. Insect Physiol. 1990, 36, 433-439. [CrossRef]

8. Beggs, J.R.; Wardle, D.A. Keystone species: Competition for honeydew among exotic and indigenous species. In Biological Invasions in New Zealand; Allen, R.B., Lee, W.G., Eds.; Springer: Berlin/Heidelberg, Germany, 2006; pp. 281-294.

9. Hunter, M.D. Insect population dynamics meets ecosystem ecology: Effects of herbivory on soil nutrient dynamics. Agr. Forest Entomol. 2001, 3, 77-84. [CrossRef]

10. Reynolds, B.C.; Hunter, M.D. Responses of soil respiration, soil nutrients, and litter decomposition to inputs from canopy herbivores. Soil Biol. Biochem. 2001, 33, 1641-1652. [CrossRef]

11. Jílková, V.; Cajthaml, T.; Frouz, J. Relative importance of honeydew and resin for the microbial activity in wood ant nest and forest floor substrate-a laboratory study. Soil Biol. Biochem. 2018, 117, 1-4. [CrossRef]

12. Jílková, V.; Jandová, K.; Cajthaml, T.; Devetter, M.; Kukla, J.; Starý, J.; Vacírová, A. Organic matter decomposition and carbon content in soil fractions as affected by a gradient of labile carbon input to a temperate forest soil. Biol. Fertil. Soils 2020, 56, 411-421. [CrossRef]

13. Michalzik, B.; Müller, T.; Stadler, B. Aphids on Norway spruce and their effects on forest-floor solution chemistry. Forest Ecol. Manag. 1999, 118, 1-10. [CrossRef]

14. Milcu, A.; Bonkowski, M.; Collins, C.; Crawley, M. Aphid honeydew-induced changes in soil biota can cascade up to tree crown architecture. Pedobiologia 2015, 58, 119-127. [CrossRef]

15. Domisch, T.; Finer, L.; Neuvonen, S.; Niemelä, P.; Risch, A.C.; Kilpeläinen, J.; Ohashi, M.; Jurgensen, M.F. Foraging activity and dietary spectrum of wood ants (Formica rufa group) and their role in nutrient fluxes in boreal forests. Ecol. Entomol. 2009, 34, 369-377. [CrossRef]

16. Stadler, B.; Schramm, A.; Kalbitz, K. Ant-mediated effects on spruce litter decomposition, solution chemistry, and microbial activity. Soil Biol. Biochem. 2006, 38, 561-572. [CrossRef]

17. Rousk, J.; Brookes, P.C.; Bååth, E. Contrasting soil pH effects on fungal and bacterial growth suggest functional redundancy in carbon mineralization. Appl. Environ. Microbiol. 2009, 75, 1589-1596. [CrossRef]

18. Nannipieri, P.; Ascher, J.; Ceccherini, M.T.; Landi, L.; Pietramellara, G.; Renella, G. Microbial diversity and soil functions. Eur. J. Soil Sci. 2017, 68, 12-26. [CrossRef]

19. Cregger, M.A.; Schadt, C.W.; McDowell, N.G.; Pockman, W.T.; Classen, A.T. Response of the soil microbial community to changes in precipitation in a semiarid ecosystem. Appl. Environ. Microbiol. 2012, 78, 8587-8594. [CrossRef]

20. Blagodatskaya, E.; Kuzyakov, Y. Active microorganisms in soil: Critical review of estimation criteria and approaches. Soil Biol. Biochem. 2013, 67, 192-211. [CrossRef]

21. Shi, S.; Richardson, A.E.; O'Callaghan, M.; DeAngelis, K.M.; Jones, E.E.; Stewart, A.; Firestone, M.K.; Condron, L.M. Effects of selected root exudate components on soil bacterial communities. FEMS Microbiol. Ecol. 2011, 77, 600-610. [CrossRef]

22. Stadler, B.; Müller, T. Aphid honeydew and its effect on the phyllosphere microflora of Picea abies (L.) Karst. Oecologia 1996, 108, 771-776. [CrossRef] 
23. Mašínová, T.; Yurkov, A.; Baldrian, P. Forest soil yeasts: Decomposition potential and the utilization of carbon sources. Fungal Ecol. 2018, 34, 10-19. [CrossRef]

24. Connell, L.; Redman, R.; Craig, S.; Scorzetti, G.; Iszard, M.; Rodriguez, R. Diversity of soil yeasts isolated from South Victoria Land, Antarctica. Microb. Ecol. 2008, 56, 448-459. [CrossRef] [PubMed]

25. Yurkov, A.M. Yeasts of the soil-Obscure but precious. Yeast 2018, 35, 369-378. [CrossRef] [PubMed]

26. Elena, S.; Renata, V. The diversity of yeasts in the agricultural soil. J. Basic Microbiol. 2003, 43, 430-436. [CrossRef]

27. Birkhofer, K.; Schöning, I.; Alt, F.; Herold, N.; Klarner, B.; Maraun, M.; Marhan, S.; Oelmann, Y.; Wubet, T.; Yurkov, A. General relationships between abiotic soil properties and soil biota across spatial scales and different land-use types. PLoS ONE 2012, 7, e43292. [CrossRef]

28. García-Ruiz, R.; Ochoa, V.; Hinojosa, M.B.; Carreira, J.A. Suitability of enzyme activities for the monitoring of soil quality improvement in organic agricultural systems. Soil Biol. Biochem. 2008, 40, 2137-2145. [CrossRef]

29. Nosrati, K.; Govers, G.; Ahmadi, H.; Sharifi, F.; Amoozegar, M.A.; Merckx, R.; Vanmaercke, M. An exploratory study on the use of enzyme activities as sediment tracers: Biochemical fingerprints? Int. J. Sediment. Res. 2011, 26, 136-151. [CrossRef]

30. Torres, I.F.; Bastida, F.; Hernández, T.; Albaladejo, J.; García, C. Enzyme activity, microbial biomass and community structure in a long-term restored soil under semi-arid conditions. Soil Res. 2015, 53, 553-560. [CrossRef]

31. Wei, S.; Emily, D.; Daniel, B.; Kannan, I. Soil enzyme activities and organic matter composition in a turfgrass chronosequence. Plant. Soil 2006, 288, 285-296.

32. Rao, M.A.; Scelza, R.; Acevedo, F.; Diez, M.C.; Gianfreda, L. Enzymes as useful tools for environmental purposes. Chemosphere 2014, 107, 145-162. [CrossRef]

33. Yu, P.; Liu, S.; Han, K.; Guan, S.; Zhou, D. Conversion of cropland to forage land and grassland increases soil labile carbon and enzyme activities in northeastern China. Agri. Ecol. Envir. 2017, 245, 83-91. [CrossRef]

34. Sinka, M.; Jones, T.H.; Hartley, S.E. Collembola respond to aphid herbivory but not to honeydew addition. Ecol. Entomol. 2009, 34, 588-594. [CrossRef]

35. Coleman, D.C.; Callaham, M.A.; Crossley Jr, D. Fundamentals of Soil Ecology; Academic Press: London, UK, 2017.

36. Schon, N.; Mackay, A.; Minor, M. Vulnerability of soil invertebrate communities to the influences of livestock in three grasslands. Appl. Soil Ecol. 2012, 53, 98-107. [CrossRef]

37. Hopkin, S.P. Biology of the Springtails:(Insecta: Collembola); OUP: Oxford, UK, 1997.

38. Whalen, J.K.; Sampedro, L. Soil Ecology and Management; CABI: Wallingford, UK, 2010.

39. Men'ko, E.; Chernov, I.Y.; Byzov, B. Interrelationships between yeast fungi and collembolans in soil. Microbiology 2006, 75, 708-715. [CrossRef]

40. Mylonakis, E.; Ausubel, F.M.; Perfect, J.R.; Heitman, J.; Calderwood, S.B. Killing of Caenorhabditis elegans by Cryptococcus neoformans as a model of yeast pathogenesis. Proc. Natl. Acad. Sci. 2002, 99, 15675-15680. [CrossRef]

41. Hoy, M.A. Soil mites (Acari: Oribatida and others). In Encyclopedia of Entomology; Capinera, J.L., Ed.; Springer: Dordrecht, The Netherlands, 2008; pp. 3463-3466.

42. Walter, D.; Hunt, H.; Elliott, E. Guilds or functional groups? An analysis of predatory arthropods from a shortgrass steppe soil. Pedobiologia 1988, 31, 247-260.

43. NIWA. CliFlo: National Institute of Water and Atmospheric Research's National Climate Database on the Web. Available online: http://cliflo.niwa.co.nz/ (accessed on 12 December 2019).

44. Hewitt, A.E. New Zealand Soil Classification, 2nd ed.; Manaaki Whenua Press: Lincoln, Canterbury, New Zealand, 1998. [CrossRef]

45. Oliver, I.; Beattie, A.J. Designing a cost-effective invertebrate survey: A test of methods for rapid assessment of biodiversity. Ecol. Appl. 1996, 6, 594-607. [CrossRef]

46. Shcherbakova, T.A. Enzymatic Activity of Soil and Transformation of Organic Matter; Springer Science \& Business Media: Berlin, Germany, 1983. (In Russian)

47. Frankenberger, W.T.; Johanson, J.B. Factors affecting invertase activity in soils. Plant. Soil 1983, 74, 313-323. [CrossRef]

48. Ross, D.J. Invertase and amylase activities as influenced by clay minerals, soil-clay fractions and topsoils under grassland. Soil Biol. Biochem. 1983, 15, 287-293. [CrossRef] 
49. Mfombep, P.M.; Senwo, Z.N. Soil maltase activity by a glucose oxidase-perioxidase system. 3 Biotech. 2012, 2, 225-231. [CrossRef]

50. Serra-Wittling, C.; Houot, S.; Barriuso, E. Soil enzymatic response to addition of municipal solid-waste compost. Biol. Fertil. Soils 1995, 20, 226-236. [CrossRef]

51. Alef, K.; Nannipieri, P. 7 - Enzyme activities. In Methods in Applied Soil Microbiology and Biochemistry; Nannipieri, P., Ed.; Academic Press: London, UK, 1995; pp. 311-373.

52. Frankenberger, W.T. Amidase Activity in Soils. Ph.D. Retrospective Theses and Dissertations, Iowa State University, Ames, IA, USA, 1980.

53. Wainwright, M.; Duddridge, J.E.; Killham, K. Assay of $\alpha$-amylase in soil and river sediments: Its use to determine the effects of heavy metals on starch degradation. Enzyme Microb. Technol. 1982, 4, 32-34. [CrossRef]

54. García-Ruiz, R.; Ochoa, V.; Vinegla, B.; Hinojosa, M.; Pena-Santiago, R.; Liébanas, G.; Linares, J.; Carreira, J. Soil enzymes, nematode community and selected physico-chemical properties as soil quality indicators in organic and conventional olive oil farming: Influence of seasonality and site features. Appl. Soil Ecol. 2009, 41, 305-314. [CrossRef]

55. Puglisi, E.; Del Re, A.; Rao, M.; Gianfreda, L. Development and validation of numerical indexes integrating enzyme activities of soils. Soil Biol. Biochem. 2006, 38, 1673-1681. [CrossRef]

56. Hinojosa, M.B.; García-Ruíz, R.; Viñegla, B.; Carreira, J.A. Microbiological rates and enzyme activities as indicators of functionality in soils affected by the Aznalcóllar toxic spill. Soil Biol. Biochem. 2004, 36, 1637-1644. [CrossRef]

57. Paz-Ferreiro, J.; Fu, S.; Méndez, A.; Gascó, G. Interactive effects of biochar and the earthworm Pontoscolex corethrurus on plant productivity and soil enzyme activities. J. Soils Sediments 2014, 14, 483-494. [CrossRef]

58. Yurkov, A.M.; Kemler, M.; Begerow, D. Assessment of yeast diversity in soils under different management regimes. Fungal Ecol. 2012, 5, 24-35. [CrossRef]

59. Ananyeva, N.D.; Susyan, E.A.; Gavrilenko, E.G. Determination of the soil microbial biomass carbon using the method of substrate-induced respiration. Eurasian Soil Sci. 2011, 44, 1215-1221. [CrossRef]

60. Anderson, J.P.E.; Domsch, K.H. A physiological method for the quantitative measurement of microbial biomass in soils. Soil Biol. Biochem. 1978, 10, 215-221. [CrossRef]

61. Ananyeva, N.D.; Rogovaya, S.V.; Ivashchenko, K.V.; Vasenev, V.I.; Sarzhanov, D.A.; Ryzhkov, O.V.; Kudeyarov, V.N. Carbon dioxide emission and soil microbial respiration activity of Chernozems under anthropogenic transformation of terrestrial ecosystems. Eurasian J. Soil Sci. 2016, 5, 146-154.

62. R Development Core Team R: A Language and Environment for Statistical Computing; R Foundation for Statistical Computing: Vienna, Austria, 2019.

63. Patel, I.I.; Shearer, D.A.; Fogarty, S.W.; Fullwood, N.J.; Quaroni, L.; Martin, F.L.; Weisz, J. Infrared microspectroscopy identifies biomolecular changes associated with chronic oxidative stress in mammary epithelium and stroma of breast tissues from healthy young women. Cancer Biol. Ther. 2014, 15, 225-235. [CrossRef]

64. Walsh, M.J.; Singh, M.N.; Pollock, H.M.; Cooper, L.J.; German, M.J.; Stringfellow, H.F.; Fullwood, N.J.; Paraskevaidis, E.; Martin-Hirsch, P.L.; Martin, F.L. ATR microspectroscopy with multivariate analysis segregates grades of exfoliative cervical cytology. Biochem. Biophys. Res. Commun. 2007, 352, 213-219. [CrossRef] [PubMed]

65. Stenberg, B.; Johansson, M.; Pell, M.; Sjödahl-Svensson, K.; Stenström, J.; Torstensson, L. Microbial biomass and activities in soil as affected by frozen and cold storage. Soil Biol. Biochem. 1998, 30, 393-402. [CrossRef]

66. Tun, K.M.; Jones, T.; Minor, M.; McCormick, A.C. Effect of willow cultivar and age on the melezitose content of giant willow aphid (Tuberolachnus salignus) honeydew. Manuscript in preparation. Agr. Forest Entomol. 2020.

67. Grace, J.B. Structural Equation Modeling and Natural Systems; Cambridge University Press: Cambridge, UK, 2006.

68. Hatcher, L. Using SAS®PROC CALIS for path analysis: An introduction. Struct. Equ. Modeling 1996, 3, 176-192. [CrossRef]

69. Arbuckle, J.L. Amos 25; IBM SPSS: Chicago, IL, USA, 2014. 
70. Cheng, F.; Peng, X.; Zhao, P.; Yuan, J.; Zhong, C.; Cheng, Y.; Cui, C.; Zhang, S. Soil microbial biomass, basal respiration and enzyme activity of main forest types in the Qinling Mountains. PLoS ONE 2013, 8, e67353. [CrossRef]

71. Sutton-Grier, A.E.; Kenney, M.A.; Richardson, C.J. Examining the relationship between ecosystem structure and function using structural equation modelling: A case study examining denitrification potential in restored wetland soils. Ecol. Modell. 2010, 221, 761-768. [CrossRef]

72. Kwan, J.L.Y.; Chan, W. Comparing standardized coefficients in structural equation modeling: A model reparameterization approach. Behav. Res. Methods 2011, 43, 730-745. [CrossRef]

73. Grace, J.B.; Bollen, K.A. Interpreting the results from multiple regression and structural equation models. Bull. Ecol. Soc. Am. 2005, 86, 283-295. [CrossRef]

74. Milcu, A.; Heim, A.; Ellis, R.J.; Scheu, S.; Manning, P. Identification of general patterns of nutrient and labile carbon control on soil carbon dynamics across a successional gradient. Ecosystems 2011, 14, 710-719. [CrossRef]

75. Stadler, B.; Mühlenberg, E.; Michalzik, B. The ecology driving nutrient fluxes in forests. In Insects and Ecosystem Function; Weisser, W.W., Siemann, E., Eds.; Springer: Berlin/Heidelberg, Germany, 2008; pp. 213-239.

76. Kaye, J.P.; Hart, S.C. Competition for nitrogen between plants and soil microorganisms. Trends Ecol. Evol. 1997, 12, 139-143. [CrossRef]

77. Petelle, M. Aphid honeydew sugars and soil nitrogen fixation. Soil Biol. Biochem. 1984, 16, 203-206. [CrossRef]

78. Joergensen, G.R.; Stefan, S. Response of soil microorganisms to the addition of carbon, nitrogen and phosphorus in a forest Rendzina. Soil Biol. Biochem. 1999, 31, 859-866. [CrossRef]

79. Islam, R.; Wright, S.R. Microbial biomass measurement methods. In Encyclopedia of Soil Science, 2nd ed.; Lal, R., Ed.; CRC: Boca Raton, FL, USA, 2004; pp. 1067-1070.

80. García-Ruiz, R.; Ochoa, M.V.; Hinojosa, M.B.; Gómez-Muñoz, B. Improved soil quality after 16 years of olive mill pomace application in olive oil groves. Agron. Sustain. Dev. 2012, 32, 803-810. [CrossRef]

81. Ruzhen, W.; Timothy, R.F.; Zhuwen, X.; Xue, W.; Mai-He, L.; Yuge, Z.; Wentao, L.; Yong, J. Coupled response of soil carbon and nitrogen pools and enzyme activities to nitrogen and water addition in a semi-arid grassland of Inner Mongolia. Plant. Soil 2014, 381, 323-336. [CrossRef]

82. Seeger, J.; Filser, J. Bottom-up down from the top: Honeydew as a carbon source for soil organisms. Eur. J. Soil Biol. 2008, 44, 483-490. [CrossRef]

83. Behan-Pelletier, V.M. Oribatid mite biodiversity in agroecosystems: Role for bioindication. Agric. Ecol. Environ. 1999, 74, 411-423. [CrossRef]

84. Jung, C.; Kim, J.W.; Marquardt, T.; Kaczmarek, S. Species richness of soil gamasid mites (Acari: Mesostigmata) in fire-damaged mountain sites. J. Asia Pac. Entomol. 2010, 13, 233-237. [CrossRef]

85. Bedano, J.C.; Cantú, M.P.; Doucet, M.E. Influence of three different land management practices on soil mite (Arachnida: Acari) densities in relation to a natural soil. Appl. Soil Ecol. 2006, 32, 293-304. [CrossRef]

86. Cao, Z.; Han, X.; Hu, C.; Chen, J.; Zhang, D.; Steinberger, Y. Changes in the abundance and structure of a soil mite (Acari) community under long-term organic and chemical fertilizer treatments. Appl. Soil Ecol. 2011, 49, 131-138. [CrossRef]

87. Walter, D.; Kethley, J.; Moore, J. Heptane flotation method for recovering microarthropods from semiarid soils, with comparison to the Merchant-Crossley high-gradient extraction method and estimates of microarthropod biomass. Pedobiologia 2013, 30, 221-232.

88. Stadler, B.; Michalzik, B.; Müller, T. Linking aphid ecology with nutrient fluxes in a coniferous forest. Ecology 1998, 79, 1514-1525. [CrossRef]

89. Johnson, D.; Leake, J.R.; Read, D.J. Liming and nitrogen fertilization affects phosphatase activities, microbial biomass and mycorrhizal colonisation in upland grassland. Plant. Soil 2005, 271, 157-164. [CrossRef]

90. Stadler, B.; Michalzik, B. Aphid infested Norway spruce are "hot spots" in throughfall carbon chemistry in coniferous forests. Can. J. For. Res. 1998, 28, 1717-1722. [CrossRef]

91. McDowell, W.H.; Likens, G.E. Origin, composition, and flux of dissolved organic carbon in the Hubbard Brook Valley. Ecol. Monogr. 1988, 58, 177-195. [CrossRef]

(C) 2020 by the authors. Licensee MDPI, Basel, Switzerland. This article is an open access article distributed under the terms and conditions of the Creative Commons Attribution (CC BY) license (http://creativecommons.org/licenses/by/4.0/). 